\title{
The Lack of Nutritional Counseling during Hospitalization
}

\author{
Luiza Antoniazzi ${ }^{\mathbb{0}}$ \\ Instituto do Coração (InCor) - Lipids, São Paulo, SP - Brazil \\ Short Editorial related to the article: Quality of Intra-Hospital Nutritional Counseling in Patients with STEMI in the Public and Private Health \\ Networks of Sergipe: The VICTIM Register
}

During the nutritional follow-up of hospitalized individuals, the nutritionist has as activities to perform the diagnosis, dietary prescription, supervise the distribution of the diets and evaluate their acceptance, and also perform nutritional counseling so that these individuals understand how a standard specific diet may be more appropriate taking into account their diagnoses and nutritional status. The number of nutritionists issued by Resolution 600 of 2018 of the Federal Council of Nutritionists is 1 professional every 15 beds of high complexity and every 30 beds of medium complexity.

Lima et al. ${ }^{2}$ evaluated in an article published in this edition whether nutritional counseling was performed in the hospital environment for patients with Acute Myocardial Infarction (AMI) and the quality of this orientation. The authors found that $57.6 \%$ of the individuals hospitalized in the public network and $70.3 \%$ private hospitals, both in Sergipe, Brazil, had received in-hospital nutritional counseling.

One possible cause of this low rate of counseling provided may be the amount of nutritionists available in hospital institutions, which is lower than predicted by the resolution. ${ }^{1}$

Seta et al., ${ }^{3}$ 2010, evaluated 8 public hospitals in 4 Brazilian states, of which none of the nutritionists evaluated reported nutritional counseling. ${ }^{3}$

Another problem is the quality of the guidance provided. It should be checked whether it meets the guidelines for preventing the occurrence of new cardiovascular events.

In the cited article there was a predominance of restrictive guidelines, especially salt and fat. About the insertion of cardioprotective foods, patients from the private network were more benefited, mainly regarding the consumption of fruits and vegetables.

The diet for prevention after acute myocardial infarction requires caloric adequacy, applied calorie restriction when necessary for the adequacy of nutritional status. It is important that the macronutrients are adequate within normality, taking into account the restriction of saturated fats and balance between the other fats as recommended by the dyslipidemia guideline. ${ }^{4-6}$ In Addition, current guidelines on prevention of cardiovascular events recommend a diet similar to the Mediterranean diet, salt intake of $<5$ g per day; $30-45$ g fibre

\section{Keywords}

Hospitalization; Healthy Diet; Risk Reduction Behavior; Inpatients; Dietetics.

Mailing Address: Luiza Antoniazzi •

Av. Dr. Eneas de Carvalho Aguiar, 44 - Lipid Unit. Postal Code 05402-000, São Paulo, SP - Brazil

E-mail: luiza.antoniazzi@hotmail.com

DOI: $10.5935 / a b c .20190172$ per day; regular consumption of fruits and vegetables per daily; regular consumption of fish and unsalted nuts daily; limited alcohol intake; and discouraging sugar-sweetened drinks. ${ }^{7,8}$

The better understanding of the food behavior is indispensable to deepen the knowledge of the determinants of the alimentary behavior, which include a complex range of nutritional, demographic, social, cultural, environmental and psychological factors. Several studies point out that the transthoracic model, ${ }^{9}$ developed by two US researchers, James O. Prochaska and Carlo DiClemente, ${ }^{10}$ in the 1980 s, can be considered a promising instrument to help understanding health-related behavioral change, and is widely used in research and clinical practice. The transthoracic model of behavior change presents 5 stages. In the pre-contemplation stage, it has not yet been considered by the individual or no changes were made to the behavior and there is no intention to adopt them in the near future. In the stage of contemplation, the individual begins to consider behavioral change. That is, it is intended to change the behavior in the future, but a deadline has not yet been set, therefore.

The decision-making individual, also called the preparation, intends to change his behavior in the near future, as in the next month. Generally, after overcoming previous attempts frustrated, small changes are made and a plan of action is adopted, still not making a serious commitment to the same. Already the individuals in action correspond to those who have in fact altered their behavior, their experiences or their environment so as to overcome barriers previously perceived. Such changes are visible and have occurred recently, as in the last six months. In the maintenance stage, the individual already changed his behavior and kept him more than six months. ${ }^{10}$

The study by Vieira et al., ${ }^{11}$ carried out with individuals after angioplasty at a hospital specialized in cardiology, in São Paulo, identified the stages of behavior change in which they were. $36 \%$ were in maintenance, $26 \%$ in preparation, $17 \%$ in pre-contemplation, $12 \%$ in action and $9 \%$ in contemplation. It is necessary for the nutrition team to create adequate food education strategies for the individuals at each stage, in order to promote adherence to a more favorable food plan and the adequacy of nutritional status.

A study with individuals from the northern region of Paraná after AMI or angioplasty aimed at identifying changes in attitudes and habits in these survivors. The main changes identified were an increase in the number of meals, an increase in fruit consumption, a reduction in the consumption of fats and fried foods, and the use of the salt shaker on the table. The number of patients who did not perform physical activity decreased. ${ }^{12}$

It is very important to evaluate the achievemente and the quality of nutritional counseling to allows the implementation of appropriate actions, since the moment after the recent cardiovascular event may favor the adoption of favorable dietary changes for these individuals. 


\section{Short Editorial}

\section{References}

1. Conselho Federal de Nutricionistas (CFN). Resolução cfn no 600, de 25 de fevereiro de 2018. Dispõe sobre a definição das áreas de atuação do nutricionista e suas atribuições, indica parâmetros numéricos mínimos de referência, por área de atuação, para a efetividade dos serviços prestados à sociedade e dá outras providências. Brasilia,2018.

2. Lima TC, Silva DG, Barreto ID, Oliveira JC, Oliveira LC, Arcelino La, et al. Quality of intra-hospital nutritional couseling in patients with STEMI in the public and private health networks of Sergipe: the VICTIM. Arq Bras Cardiol. 2019; 113(2):260-269.

3. Seta MH, O’Dwyer G, Henriques P, Sales GLP. Cuidado nutricional em hospitais públicos de quatro estados brasileiros: contribuições da avaliação em saúde à vigilância sanitária de serviços Ciência \& Saúde Coletiva.2010;15(supl 3):3413-22.

4. Piegas LS, Timerman A, Feitosa GS, Nicolau JC, Mattos LAP, Andrade MD et al.,Sociedade Nrasileira de Cardiologia. V Diretriz da Sociedade Brasileira de Cardiologia sobre Tratamento do Infarto Agudo do Miocárdio com Supradesnível do Segmento ST. Arq Bras Cardiol. 2015; 105(2 supl 1):1-105.

5. National Cholesterol Education Program (NCEP) Expert Panel on Detection, Evaluation, and Treatment of High Blood Cholesterol in Adults (Adult Treatment Panel III). Third Report of the National Cholesterol Education Program (NCEP) Expert Panel on Detection, Evaluation, and Treatment of High Blood Cholesterol in Adults (Adult Treatment Panel III) final report. Circulation. 2002;106(25):3143-421.
6. Xavier HT, Izar MC, Faria Neto JR, Assad MH, Rocha VZ, Sposito AC et al. V Diretriz brasileira de dislipidemias e prevenção da aterosclerose. Arq Bras Cardiol. 2017;109(2 supl 1):1-76.

7. Piepoli MF, Hoes AW, Agewall S, Albus C, Brotons C, Catapano AL et al. 2016 European Guidelines on cardiovascular disease prevention in clinical practice: The Sixth Joint Task Force of the European Society of Cardiology and Other Societies on Cardiovascular Disease Prevention in Clinical Practice (constituted by representatives of 10 societies and by invited experts). Developed with the special contribution of the European Association for Cardiovascular Prevention \& Rehabilitation (EACPR). Eur Heart J. 2016;37(29):2315-81.

8. The Task Force for the management of acute myocardial infarction in patients presenting with ST-segment elevation of the European Society of Cardiology (ESC). 2017 ESC Guidelines for the management of acute myocardial infarction in patients presenting with ST-segment elevation. Eur HeartJ. 2018;39:119-77.

9. Toral N, Slater B. Abordagem do modelo transteórico no comportamento alimentar Ciência \& Saúde Coletiva. 2007;12(6):1641-50.

10. Prochaska JO, DiClemente C,Norcross JC. In search of how people change application to addictive behaviors. Am Physiol. 1992;47(9):1102-14.

11. Vieira LP, Nobre MR, Queiroz GG. Eating behavior and nutritional status in patients who underwent coronary angioplasty. Nutr Hosp. 2012;27(1):281-7.

12. Gallo AM, Laurenti R. Mudança de hábitos e atitudes em sobreviventes de infarto agudo do miocárdio e angioplastia primária. Saúde. 2014;40(2):59-66. 